\author{
Нікішина О.В. \\ доктор економічних наук, старший науковий співробітник \\ завідувач відділу ринкових механізмів та структур \\ Інститут проблем ринку та економіко-екологічних досліджень НАН України \\ Французький бульвар, 29, м. Одеса, Україна, 65044 \\ E-mail: ksenkych@gmail.com \\ ORCID ID: 0000-0002-7172-3551
}

\title{
МЕТОДИЧНІ ПОЛОЖЕННЯ ЩОДО ОЦІНКИ ПРИРОДНО-РЕСУРСНОГО ПОТЕНЦІАЛУ СІЛЬСЬКОГО ГОСПОДАРСТВА У КООРДИНАТАХ СТАЛОГО РОЗВИТКУ УКРАЇНИ *
}

\begin{abstract}
У статті розроблено методичні положення щодо комплексної оцінки компонентів природноресурсного потенціалу сільського господарства на засадах сталого розвитку. Обґрунтовано систему комплементарних індикаторів сталого розвитку, «зеленого» зростання та авторських показників у відповідності до наукових принципів, яка покликана забезпечити всебічну оцінку використання, трансформації, відновлення та охорони природно-ресурсного потенціалу аграрного сектору крізь призму сталого розвитку. Запропоновано низку авторських показників з акцентом на індикатори ресурсної й екологічної продуктивності валової доданої вартості сільського господарства. 3 використанням розроблених методичних положень проведено оцінку стану деяких компонентів природно-ресурсного потенціалу агросектору, зокрема, земельних і водних ресурсів, сфери поводження з відходами та інвестиційного забезпечення раціонального природокористування. За результатами оцінки визначено позитивні і негативні тенденції у використанні природно-ресурсного потенціалу агросфери, окреслено головні напрями їх подолання.
\end{abstract}

Ключові слова: природно-ресурсний потенціал, сталий розвиток, аграрний сектор, індикатори, оцінка, раціональне природокористування.

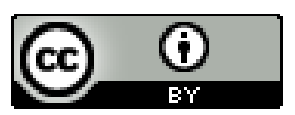

This work is licensed under a Creative Commons Attribution 4.0 International License http://creativecommons.org/licenses/by/4.0/
Постановка проблеми та її зв'язок 3 важливими науковими та практичними завданнями. Сучасний вектор соціально-економічної політики держави характеризується активізацією програм впровадження Цілей сталого розвитку (далі - ЦСР) до 2030 р., проголошених резолюцією Генеральної Асамблеї ООН № 70/1 від 25.09.2015 р. [1]. В Україні відбувається процес інституціоналізації компонентів збалансованого розвитку. Так, Указом Президента №722/2019 від 30.09.2019p. забезпечення національних інтересів України щодо сталого розвитку економіки, громадянського суспільства і держави для досягнення зростання рівня та якості життя населення визнано пріоритетними на період до 2030 р. Цим Указом передбачено врахування ЦСР у наукових дослідженнях, упровадження дієвої системи моніторингу реалізації ЦСР України до 2030 р. та оприлюднення його результатів щороку до 1 березня року, який настає за звітним [2]. Відтак, інституційні нововведення актуалізують необхідність нових методичних розробок у площині сталого розвитку, які можуть бути корисними різним групам стейкхолдерів, зокре- ма, державним, профільним та міжнародним інституціям, суб'єктам господарювання та суспільству в цілому для різнобічної оцінки прогресу або регресу сталого розвитку в Україні.

Важлива роль у збалансованому розвитку держави належить сільському господарству та його природно-ресурсному потенціалу (далі - ПРП). У Стратегії сталого розвитку України до 2030 р. невід'ємною складовою стратегічної цілі 2 «Забезпечення сталого галузевого та регіонального розвитку» визнано сприяння сталому розвитку агропромислового комплексу (операційна ціль 2.1) [3]. Завдання, об'єднані у межах даної операційної цілі, корелюють iз завданнями 2-ї глобальної ЦСР «Подолання голоду, досягнення продовольчої безпеки, поліпшення харчування і сприяння сталому розвитку сільського господарства» [1]. Водночас для різнобічної оцінки використання, трансформації, відновлення та охорони ПРП сільського господарства можна використати систему індикаторів не тільки 2-ї, а й 6-ї, 12-ї, 15-ї ЦСР, що обумовлює необхідність проведення нових методичних досліджень у цьому напрямі.

* Публікацію підготовлено в межах НДР «Домінанти інвестиційно-інноваційної політики природокористування національної економіки» за рахунок коштів бюджетної програми «Підтримка розвитку пріоритетних напрямів наукових досліджень» (КПКВК 6541230). 
Практична значимість розширення системи індикаторів полягає в поглибленні аналітичної бази та підвищенні можливостей оновленої методології дослідження (сукупності способів, прийомів і методів) щодо ідентифікації проблемних місць у процесі сталого розвитку, обгрунтування напрямів, механізмів і інструментів їх подолання в умовах України.

Аналіз останніх публікацій по проблемі. Теоретико-методичне осмислення питання раціонального використання ПРП аграрної сфери є предметом активного наукового пошуку. Проблеми ефективного використання й відновлення компонентів ПРП сільського господарства висвітлені у працях O.I. Дребота [4], М.В. Калінчика [5], М.А. Лендєла, М.Й. Маліка, П.Т. Саблука, А.М. Сундука, М.А. Хвесика [6] та інших науковців. Питання методичного забезпечення моніторингу ЦСР в Україні грунтовно досліджено у працях учених Національної академії наук України, зокрема, Інституту демографії та соціальних досліджень ім. М.В. Птухи [7], Інституту проблем ринку та економіко-екологічних досліджень $[8,9]$. Методичні підходи до оцінки «зеленої» трансформації країни на основі показників «зеленого» зростання ОЕСР розроблені Л. Мусіною та Т. Квашою у праці [10]. Водночас недостатньо дослідженим залишається питання оцінки ПРП агросфери на основі системи комплементарних індикаторів сталого розвитку, розробку та моніторинг якої актуалізують чинні інституційні трансформації в державі на шляху її збалансованого розвитку.

Формулювання цілей дослідження. Мета статті - розробка методичних положень щодо комплексної оцінки складових ПРП сільського господарства України на основі системи комплементарних індикаторів сталого розвитку, «зеленого» зростання й авторських показників та оцінка на даній методичній платформі стану деяких компонентів ПРП агросектору, зокрема, земельних і водних ресурсів, сфери поводження з відходами та інвестиційного забезпечення раціонального природокористування. У ході дослідження використано такі методи: логічноструктурного і системного аналізу, синтезу і групувань, порівняння, графічного, базисні та ланцюгові індекси.

Виклад основних результатів та їх обгрунтування. Методичні положення щодо комплексної оцінки ПРП сільського господарства, розроблені автором, комплементарно поєднують ключові індикатори сталого розвитку у розрізі чотирьох ЦСР $(2,6$, $12,15)$, показники «зеленого» зростання за Методикою ОЕСР в частині ресурсної продуктивності, економічних можливостей і відповідей політики, а також низку авторських індикаторів, для розрахунку яких в Україні створена достовірна інформаційна база (таблиця 1). Доцільність включення в систему «зелених» показників обумовлена, з одного боку, їх здатністю до більш глибокого розкриття характеристик ПРП агросфери, 3 іншого, роллю концепції «зеленого» зростання як прикладного інструменту впровадження цілей сталого розвитку.

Ключові індикатори в оціночній системі згруповані за складовими ПРП сільського господарства (земельні, водні, трудові та матеріальні ресурси) та низкою завдань сталого розвитку, які є наслідком ефективного використання ПРП агросектору, зокрема, забезпечення продовольчої безпеки, зменшення втрат агропродукції у логістичних ланцюгах, обсягів утворення відходів, зростання інвестицій в раціональне природокористування (див. табл. 1). Конструювання системи комплементарних індикаторів здійснювалося 3 урахуванням таких принц̧ипів: (1) комплексність i взаємопов'язаність; (2) об'єктивність і достовірність; (3) можливість міжсекторального порівняння; (4) цілеспрямованість орієнтація на цілі та стратегію сталого розвитку економічних систем мікро-, мезо- та макрорівнів; (5) гнучкість і науковість; (6) транспарентність - прозорість для стейкхолдерів. Значення останнього принципу зростає у зв'язку з впровадженням Указу Президента №722/2019 в частині створення відкритої системи моніторингу ЦСР в Україні [2].

Використовуючи запропоноване методичне забезпечення, проведемо оцінку стану використання ПРП сільського господарства України. Враховуючи його тісний органічний зв'язок із природними ресурсами, в даному дослідженні акцентуємо увагу на діагностиці земельних і водних ресурсів агросектору крізь призму сталого розвитку. Порівняння фактичних значень індикаторів здійснюється із цільовими орієнтирами сталого розвитку 2020 р. [7], а також із базовим показником 2010 року.

Таблиця 1

Методичні положення щодо комплексної оцінки складових природно-ресурсного потенціалу сільського господарства України у контексті сталого розвитку*

\begin{tabular}{|c|c|c|}
\hline $\begin{array}{c}\text { Складові } \\
\text { потенціалу / } \\
\text { завдання } \\
\end{array}$ & $\begin{array}{c}\text { Цілі сталого розвит- } \\
\text { ку/ індикатори «зеле- } \\
\text { ного» зростання } \\
\end{array}$ & Ключові індикатори \\
\hline $\begin{array}{l}\text { 1. Земельні } \\
\text { ресурси }\end{array}$ & $\begin{array}{c}\text { ЦСР } 15 \text { «Захист та } \\
\text { відновлення екосис- } \\
\text { тем суші» } \\
\text { Завдання } 15.3 \text { «Відно- } \\
\text { вити деградовані землі } \\
\text { та грунти з викорис- } \\
\text { танням інноваційних } \\
\text { технологій» }\end{array}$ & $\begin{array}{l}\text { 1.Площа орних земель (ріллі), тис. га } \\
\text { 2. Частка площі орних земель (ріллі) у загальній території країни,\% } \\
\text { 3.Площа СГ*** угідь екстенсивного використання (сіножатей, па- } \\
\text { совищ), тис. га } \\
\text { 4.Частка площі СГ угідь екстенсивного використання (сіножатей, } \\
\text { пасовищ) у загальній території країни, \% } \\
\text { 5.Площа земель органічного виробництва, тис. га } \\
\text { 6. Частка органічних угідь у загальній території країни, \% ** } \\
\text { 7. Індекс кількості органічних господарств в Україні, \% до } \\
\text { 2005р.** }\end{array}$ \\
\hline
\end{tabular}


Продовження табл.1

\begin{tabular}{|c|c|c|}
\hline $\begin{array}{c}\text { Складові } \\
\text { потенціалу / } \\
\text { завдання } \\
\end{array}$ & $\begin{array}{c}\text { Цілі сталого розвит- } \\
\text { ку/ індикатори «зеле- } \\
\text { ного» зростання }\end{array}$ & Ключові індикатори \\
\hline & $\begin{array}{c}\text { Методика ОЕСР: } \\
\text { Індикатори екологічної } \\
\text { та ресурсної продукти- } \\
\text { вності }\end{array}$ & $\begin{array}{l}\text { 1. Внесення азотних та фосфорних добрив, т/1000 га } \\
\text { 2. Баланс гумусу в грунтах України, т/га } \\
\text { 3. Баланс поживних речовин в грунтах України, т/га } \\
\text { 4. Обсяг внесених добрив (мінеральних і органічних) сільського- } \\
\text { сподарськими підприємствами на } 1 \text { га посівної площі, кг/га ** } \\
\text { 5. Частка удобреної площі у посівній площі сільськогосподарсь- } \\
\text { ких підприємств, \% (за мінеральними й органічними добривами) } \\
\text { ** }\end{array}$ \\
\hline $\begin{array}{l}\text { 2. Водні ресур- } \\
\text { си }\end{array}$ & $\begin{array}{c}\text { ЦСР } 6 \text { «Чиста вода та } \\
\text { належні санітарні } \\
\text { умови» }\end{array}$ & $\begin{array}{l}\text { 1.Обсяги скидів забруднених стічних вод у водні об’єкти, } \\
\text { млн.куб.м. } \\
\text { 2.Частка скидів забруднених стічних вод у водні об’єкти у зага- } \\
\text { льному обсязі скидів, \% } \\
\text { 3. Індекс споживання прісної води сільським господарством, \% } \\
\text { 4. Водоємність ВВП, куб.м використаної води на } 1000 \text { грн. ВВП } \\
\text { (у фактичних цінах; у цілому по економіці) } \\
\text { 5. Водоємність ВДВ сільського господарства, куб.м використаної } \\
\text { води на } 1000 \text { грн. ВДВ (у фактичних цінах) ** } \\
\text { 6.Індекс водоємності ВДВ сільського господарства, \%** } \\
\text { 7. Обсяги втрат віртуальної води, млн. грн. ** }\end{array}$ \\
\hline $\begin{array}{l}\text { 3. Трудові ре- } \\
\text { сурси }\end{array}$ & $\begin{array}{c}\text { ЦСР } 2 \text { «Подолання } \\
\text { голоду, розвиток } \\
\text { сільського господарс- } \\
\text { тва» }\end{array}$ & $\begin{array}{l}\text { 1. Продуктивність праці в сільському господарстві на 1зайнятого } \\
\text { 2. Індекс сільськогосподарської продукції: } \\
\text { а) за видами діяльності сільського господарства (рослинництво, } \\
\text { тваринництво); } \\
\text { б) за категоріями виробників (підприємства, у т.ч. фермерські } \\
\text { господарства; господарства населення) }\end{array}$ \\
\hline $\begin{array}{l}\text { 4. Матеріальні } \\
\text { ресурси }\end{array}$ & $\begin{array}{c}\text { Методика ОЕСР: } \\
\text { Індикатори екологічної } \\
\text { та ресурсної продукти- } \\
\text { вності }\end{array}$ & $\begin{array}{l}\text { 1. Матеріальна продуктивність ВВП, грн./кг (в цілому по еконо- } \\
\text { міці) } \\
\text { 2. Матеріальна продуктивність ВДВ сільського господарства, } \\
\text { грн./кг** } \\
\text { 3. Індекс матеріальної продуктивності ВДВ сільського господар- } \\
\text { ства, \%** }\end{array}$ \\
\hline $\begin{array}{l}\text { 5. Забезпечення } \\
\text { продовольчої } \\
\text { безпеки }\end{array}$ & $\begin{array}{c}\text { ЦСР } 2 \text { «Подолання } \\
\text { голоду, розвиток } \\
\text { сільського господарс- } \\
\text { тва» }\end{array}$ & $\begin{array}{l}\text { 1.Індекс виробництва харчових продуктів, \% } \\
\text { 2.Частка продукції харчової промисловості та переробки аграр- } \\
\text { ної сировини в експорті груп 1-24 УКТЗЕД, \% } \\
\text { 3.Індекс споживчих цін на продукти харчування (середньоріч- } \\
\text { ний) за основними групами продуктів, \% } \\
\text { 4.Споживання м’яса в розрахунку на одну особу, кг/рік } \\
\text { 5. Споживання молока в розрахунку на одну особу, кг/рік } \\
\text { 6. Споживання фруктів в розрахунку на одну особу, кг/рік }\end{array}$ \\
\hline $\begin{array}{c}\text { 6. Скорочення } \\
\text { втрат агропро- } \\
\text { дукції у логіс- } \\
\text { тичних ланцю- } \\
\text { гах }\end{array}$ & $\begin{array}{c}\text { ЦСР } 12 \text { «Відповіда- } \\
\text { льне споживання та } \\
\text { виробництво» }\end{array}$ & $\begin{array}{l}\text { 1. Частка післязбиральних втрат у загальному виробництві зер- } \\
\text { нових культур, \% } \\
\text { 2. Частка післязбиральних втрат у загальному виробництві ово- } \\
\text { чів та баштанних культур, \% } \\
\text { 3. Частка післязбиральних втрат у загальному виробництві пло- } \\
\text { дово-ягідних культур, \%** }\end{array}$ \\
\hline $\begin{array}{l}\text { 7. Зменшення } \\
\text { обсягів утворе- } \\
\text { них відходів, } \\
\text { зростання об- } \\
\text { сягів їх пере- } \\
\text { робки та по- } \\
\text { вторного вико- } \\
\text { ристання }\end{array}$ & $\begin{array}{c}\text { ЦСР } 12 \text { «Відповіда- } \\
\text { льне споживання та } \\
\text { виробництво» }\end{array}$ & $\begin{array}{l}\text { 1. Обсяг утворених відходів усіх видів економічної діяльності на } \\
\text { одиницю ВВП, кг на } 1000 \text { дол. ПКС } 2011 \text { р. } \\
\text { 2. Частка спалених та утилізованих відходів у загальному обсязі } \\
\text { утворених відходів, \% } \\
\text { 3. Обсяг утворених відходів у сільському господарстві, тис. т } \\
\text { 4. Частка утворених відходів у сільському господарстві у загаль- } \\
\text { ному обсязі утворених відходів в економіці, \%** } \\
\text { 5. Відходоємність ВДВ сільського господарства, кг на } 1000 \text { грн. } \\
\text { ВДП (у фактичних цінах) ** } \\
\text { 6. Індекс відходоємності ВДВ сільського господарства, \%** }\end{array}$ \\
\hline
\end{tabular}


Продовження табл. 1

\begin{tabular}{|c|c|c|}
\hline $\begin{array}{c}\text { Складові } \\
\text { потенціалу / } \\
\text { завдання }\end{array}$ & $\begin{array}{c}\text { Цілі сталого розвит- } \\
\text { ку/ індикатори «зеле- } \\
\text { ного» зростання }\end{array}$ & Ключові індикатори \\
\hline $\begin{array}{c}\text { 8. Зростання } \\
\text { інвестицій в } \\
\text { раціональне } \\
\text { природо- } \\
\text { користування }\end{array}$ & $\begin{array}{c}\text { Методика ОЕСР: } \\
\text { Індикатори економіч- } \\
\text { них можливостей та } \\
\text { відповідей політики }\end{array}$ & $\begin{array}{l}\text { 1.Капітальні інвестиції та поточні видатки на захист навколиш- } \\
\text { нього середовища за рахунок коштів Державного бюджету (млн. } \\
\text { грн.; \% до ВВП). } \\
\text { 2. Розподіл капітальних інвестицій (поточних видатків) за вида- } \\
\text { ми природоохоронної діяльності, \% до загального обсягу } \\
\text { 3. Частка інвестицій на захист навколишнього середовища в } \\
\text { сільському господарстві, \% до загального обсягу** } \\
\text { 4. Частка капітальних інвестицій на охорону природного середо- } \\
\text { вища в сільському господарстві, \% до загального обсягу інвести- } \\
\text { цій, ВДВ сільського господарства** }\end{array}$ \\
\hline
\end{tabular}

*Розроблено автором із використанням джерел $[7,10]$;

**Індикатор запропоновано автором;

***СГ- сільськогосподарський.

Головні індикатори, що характеризують стан використання земельних ресурсів України, узагальнено в таблиці 2. У 2018 р. площа орних земель у країні склала 32544,3 тис. га, що на 4,6 \% вище цільового індикатора 2020 р. Частка площі ріллі у загальній території країни досягла в звітному році 53,9 \%, перевищивши цільовий орієнтир на 2,3 \% [7, с.109]. Фактичні показники площ сільськогосподарських угідь екстенсивного використання та їх частки в загальній території країни (7820,9 тис. га і 13 \%) є нижчими цільових індикаторів сталого розвитку (8389,3 тис. га і 13,9 \% відповідно) [7, с.109], що є свідченням надмірної розораності земель. Порівняно з 2010 р. площі орних земель зросли на 0,2 \% за одночасного скорочення площ сіножатей i пасовищ на $0,9 \%$ (див. табл. 2).

Таблиця 2

Головні індикатори стану використання земельних ресурсів сільського господарства України"

\begin{tabular}{|c|c|c|c|c|c|c|c|c|}
\hline \multirow{2}{*}{ Індикатори } & \multicolumn{7}{|c|}{ Роки } & \multirow{2}{*}{$\begin{array}{r}\text { Цільовий } \\
\text { індикатор } \\
2020 \text { р.**** }\end{array}$} \\
\hline & 2010 & 2013 & 2014 & 2015 & 2016 & 2017 & 2018 & \\
\hline $\begin{array}{l}\text { 1. Площа орних земель (ріл- } \\
\text { лі), тис. га }\end{array}$ & $\begin{array}{c}32476 \\
5\end{array}$ & $\begin{array}{c}32525 \\
5 \\
\end{array}$ & $\begin{array}{c}32531 \\
1\end{array}$ & $\begin{array}{c}32541, \\
3 \\
\end{array}$ & $\begin{array}{c}32543 \\
4\end{array}$ & $\begin{array}{c}32544, \\
3\end{array}$ & $\begin{array}{c}32544 \\
3\end{array}$ & 31150,9 \\
\hline у\% до загальної території & 53,8 & 53,9 & 53,9 & 53,9 & 53,9 & 53,9 & 53,9 & 51,6 \\
\hline$y \%$ до $C \Gamma^{* *} y z i \partial b$ & 78,1 & 78,3 & 78,4 & 78,4 & 78,4 & 78,4 & 78,4 & $\mathrm{X}$ \\
\hline $\begin{array}{l}\text { 2. Площа СГ угідь екстенси- } \\
\text { вного використання (пасо- } \\
\text { вищ, сіножатей), тис.га }\end{array}$ & 7892,8 & 7855,6 & 7848,3 & 7840,5 & 7833,8 & 7820,9 & 7820,9 & 8389,3 \\
\hline у\% до загальної території & 13,1 & 13,0 & 13,0 & 13,0 & 13,0 & 13,0 & 13,0 & 13,9 \\
\hline $\begin{array}{l}\text { 3. Площа органічних угідь, } \\
\text { тис. га }\end{array}$ & 270,2 & 393,4 & 400,8 & 410,6 & 411,2 & 420,0 & 420,0 & 500,0 \\
\hline у\% до загальної території & 0,45 & 0,65 & 0,66 & 0,68 & 0,68 & 0,70 & 0,70 & $\mathrm{X}$ \\
\hline y\% до СГ угіды & 0,65 & 0,95 & 0,97 & 0,99 & 0,99 & 1,01 & 1,01 & 1,1 \\
\hline$y \%$ до $2010 p$ & 100,0 & 145,6 & 148,3 & 151,9 & 152,2 & 155,4 & 155,4 & $X$ \\
\hline $\begin{array}{l}\text { 4. Кількість органічних гос- } \\
\text { подарств, одиниць }\end{array}$ & 142 & 175 & 182 & 210 & 360 & 375 & 375 & $\mathrm{X}$ \\
\hline$y \%$ до $2010 p$ & 100,0 & 123,2 & 128,2 & 147,9 & 253,5 & 264,1 & 264,1 & $\mathrm{X}$ \\
\hline $\begin{array}{l}\text { 5. Удобрена площа мінера- } \\
\text { льними добривами, млн. га }\end{array}$ & 12,6 & 15,3 & 14,7 & 14,5 & 15,6 & 16,5 & 16,1 & $\mathrm{X}$ \\
\hline$y \%$ до $2010 p$ & 100,0 & 121,4 & 116,7 & 115,1 & 123,8 & 131,0 & 127,8 & $\mathrm{X}$ \\
\hline $\begin{array}{l}\text { 6. Удобрена площа органіч- } \\
\text { ними добривами, млн. га }\end{array}$ & 0,4 & 0,4 & 0,4 & 0,4 & 0,5 & 0,5 & 0,8 & $\mathrm{X}$ \\
\hline y\% до $2010 p$. & 100,0 & 100,0 & 100,0 & 100,0 & 125,0 & 125,0 & 200,0 & $X$ \\
\hline
\end{tabular}


Продовження табл. 2

\begin{tabular}{|l|c|c|c|c|c|c|c|c|}
\hline $\begin{array}{l}\text { 7. Внесено під посіви СГ } \\
\text { культур мінеральних доб- } \\
\text { рив, тис. тонн }\end{array}$ & 1060,6 & 1489,5 & 1469 & 1412 & 1724,4 & 2023,8 & 2147,4 & $\mathrm{X}$ \\
\hline$y \%$ до 2010 $p$. & 100,0 & 140,4 & 138,5 & 133,1 & 162,6 & 190,8 & 202,5 & $\mathrm{X}$ \\
\hline $\begin{array}{l}\text { 8. Внесено під посіви СГ } \\
\text { культур органічних добрив, } \\
\text { тис. тонн }\end{array}$ & 9874 & 9603 & 9861 & 9636 & 9133 & 9250 & 10644 & $\mathrm{X}$ \\
\hline$y \%$ до 2010 $p$. & 100,0 & 97,3 & 99,9 & 97,6 & 92,5 & 93,7 & 107,8 & $\mathrm{X}$ \\
\hline $\begin{array}{l}\text { 9. Обсяг внесення азотних і } \\
\text { фосфорних добрив на 1 га } \\
\text { посівної площі, кг }\end{array}$ & 52 & 67 & 70 & 68 & 83 & 94 & 102 & $\mathrm{X}$ \\
\hline$y \%$ до 2010 $p$. & 100,0 & 128,8 & 134,6 & 130,8 & 159,6 & 180,8 & 196,2 & $\mathrm{X}$ \\
\hline
\end{tabular}

Розраховано автором за даними Державної служби статистики України [11-14];

** СГ - сільськогосподарський;

*** За даними джерела [7].

За рівнем забезпеченості сільськогосподарськими угіддями (0,87 га/особу) Україна посідає друге місце в Європі (середній індикатор для ЄС складає 0,43 га/особу) і є однією із найбільш землезабезпечених країн світу. Водночас продуктивні землі використовуються не достатньо ефективно, вони потерпають від забруднення й ерозії. Водна та вітрова ерозія обумовлюють до 15 т / га середньорічних втрат грунтів. Втрати гумусу та поживних речовин спостерігаються на 43 \% загальної площі. Значні території забруднені внаслідок господарської діяльності, понад 57 \% їх площ в Україні визнані як еродовані [7, с.110].

За досліджуваний період спостерігається стійка тенденція зростання площ органічних угідь, яка посилилися у 2013 р. (див табл. 2). У 2018 р. площа сертифікованих угідь в державі зросла порівняно 3 2010 p. на 55,4 \% і досягла 420 тис. га, що складає $1,01 \%$ від загальної площі сільськогосподарських угідь і практично досягає рівня цільового індикатора 2020 року $(1,1 \%)$. До 2030 р. заплановано зростання органічних площ до 3000 тис. га [7, с. 108], тобто в 7 разів. Кількість органічних господарств в Україні досягла 375 одиниць, збільшившись порівняно 3 2010 р. у 2,6 рази.

Слід відзначити, що тенденція збільшення площ органічних угідь не супроводжується достатніми темпами зростання обсягів внесених органічних добрив. У 2010-2017 pp. величина удобреної площі органічними добривами (0,4-0,5 млн. га) залишалася постійною, і лише у 2018 рр. відбулося зростання показника на 0,4 млн. га. Загалом у 2018 р. під посіви сільськогосподарських культур було внесено 10644 тис. т органічних добрив, що на 7,8 \% більше індикатора 2010 року (див. табл. 2).

У 2004-2014 рр. вітчизняні аграрні підприємства вносили менше 1 тонни гною на гектар, тоді як мінімальна норма для забезпечення бездефіцитного балансу гумусу в Україні становить 8-14 т/ га. Головною причиною $є$ занепад тваринництва, що призвело до нестачі добрив [10, с. 26]. Навпаки, внесення мінеральних добрив під посіви сільськогосподарських культур зростає - від 1061 тис. т у 2010 р. до
2147,4 тис. т у 2018 р. (див. табл. 2). При цьому приріст обсягів внесення мінеральних добрив агропідприємствами (на 102,5 \%) значно перевищує приріст внесення органічних добрив (на 7,8 \%).

Обсяг внесених азотних і фосфорних добрив вітчизняними агровиробниками зріс з 52 кг/га в 2010 р. до 102 кг/га в 2018 р. (на 96,2 \%). За даним індикатором Україна близька до таких країн ОЕСР, як США і Фінляндія [10, с. 27]. За показником «Ефективність використання азотних добрив», як складової Індексу екологічної ефективності 2018 р., Україна посіла 17 сходинку серед 180 країн, отримавши 57,55 балів [15]. 3 огляду на несприятливий вплив мінералізації сільського господарства на стан природного середовища, важливим завданням $є$ дотримання аграрними підприємствами технологій застосування мінеральних добрив, оптимізації їх обсягів, нарощування обсягів внесення органічних добрив.

Грунти та їх стан $\epsilon$ основною компонентою ПРП сільського господарства, чинником забезпечення національної продовольчої безпеки, продуктивності аграрного виробництва. Тому аналіз балансу гумусу й поживних речовин є невід'ємною складовою методичних положень щодо оцінки ПРП сільського господарства (див. табл. 1). Баланс гумусу в грунтах України вказує на стійку тенденцію зменшення запасів гумусу (рис. 1). Однією з основних причин такого стану є недостатнє внесення органічних добрив агровиробниками.

Баланс поживних речовин в грунтах України досяг мінімального значення у 2001-2005 pp. (136 кг/га) та зріс у 2011-2012 pp. (-89 кг/га), однак не досягнув позитивного значення (рис. 2). Свого максимального рівня (30 кг/га) за досліджуваний період баланс поживних речовин досягнув у 1981-1985 pр. Відтак, через надмірну розораність, дефіцитний баланс гумусу і поживних речовин, недостатнє внесення органічних добрив, забруднення, грунти України в сучасних умовах продовжують деградувати [16, c. 107]. Досягнення нейтрального рівня деградації земель стає основою земельної політики, яку пропагує Конвенція боротьби з опустелюванням [7, с. 110]. 


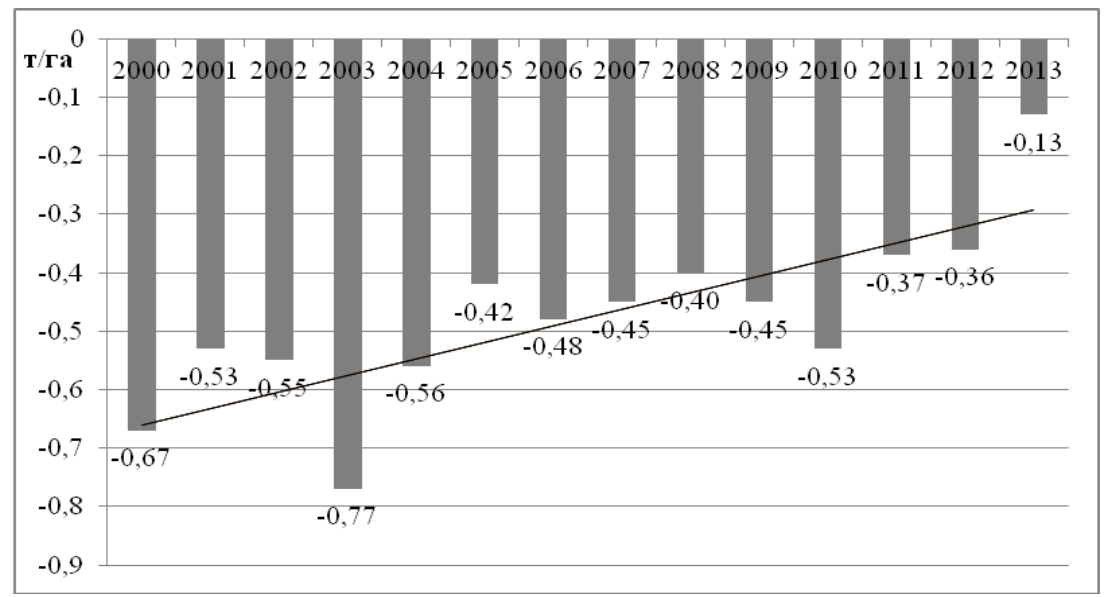

Рис. 1. Баланс втрати гумусу в грунтах України, т/га*

* побудовано за даними Міністерства екології та природних ресурсів України [16, с.106]

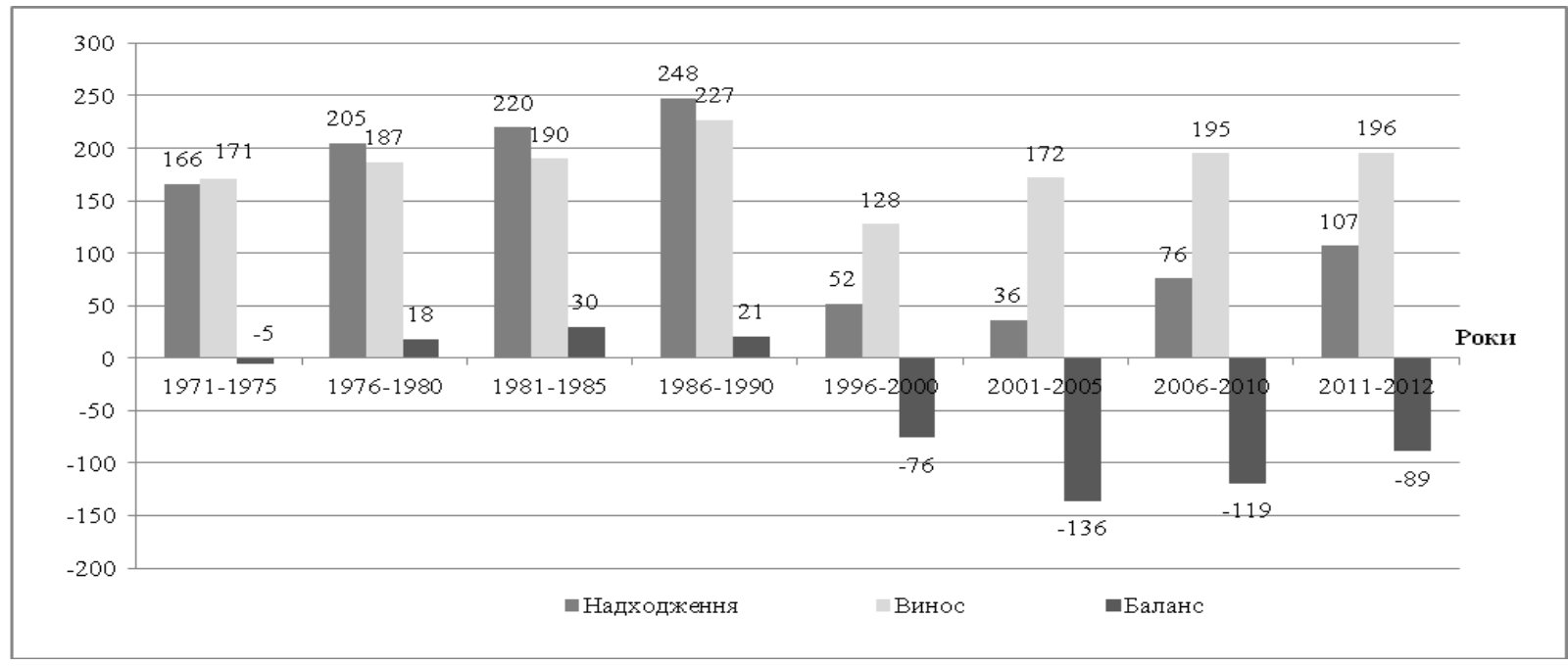

Рис. 2. Баланс втрати поживних речовин в грунтах України*

"побудовано автором за даними Міністерства екології та природних ресурсів України [16, с.106]

Окрім грунтів, важливим природним ресурсом сільського господарства є вода. Для оцінки ефективності використання водних ресурсів у системі моніторингу ЦСР 6 «Чиста вода та належні санітарні умови» передбачено низку показників, у т.ч. індикатор водоємності ВВП, який розраховується для економіки держави в цілому (див. табл. 1). Поряд із загальним показником, ми пропонуємо здійснювати розрахунок секторальних індикаторів, зокрема, індикатор водоємності валової доданої вартості (ВДВ) сільського господарства, який дозволяє встановити зв'язок між макроекономічним та екологічним показником. Результати проведених автором розрахунків у даному напрямі наведено в таблиці 3 .

За період 2010-2018 рр. водоємність ВВП в Україні зменшилася в 4,3 рази - $313,75 \mathrm{~m}^{3}$ на тис. грн.

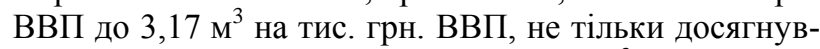
ши цільового значення 2020 року $\left(3,2 \mathrm{~m}^{3}\right.$ на тис. грн. ВВП), але й покращивши його. Тенденцію зменшення водоємності ВВП обумовило зменшення обсягів забраної води з природних водних об’єктів (у 2018 р. базовий індекс склав 75 \%) за одночасного зростання показника ВВП у фактичних цінах (у звітному році базовий індекс досягнув 273,7 \%) [9].

Водоємність ВДВ сільського господарства у

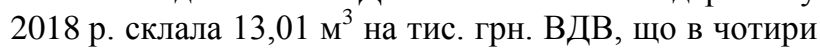
рази вище середнього показника по економіці та $€$ свідченням істотних обсягів водоспоживання аграрним сектором. За статистичними даними, у 2018 р. за обсягами забору прісної води (4698 млн. м³) серед секторів національної економіки сільське господарство посіло перше місце із часткою 43,9 \% (частка енергетики склала $24 \%$ \% [13, с. 82].

За 2010-2018 рр. водоємність ВДВ сільського господарства зменшилася на $81,8 \%$ за рахунок скорочення обсягів забору води (базовий індекс 79,3\%) на фоні зростання ВДВ у 4,4 рази. Слід відзначити, що подвійне скорочення індикатора у 2015 р. певним чином було пов'язане зі зменшенням обсягів виробництва сільгосппродукції, індекс якого склав 95,2 \%; у 2017 р. означена тенденція теж вплинула на скорочення водоємності ВДВ сектору (див. табл. 3). 
Динаміка водосмності валової доданої вартості сільського господарства України*

\begin{tabular}{|c|c|c|c|c|c|c|c|c|}
\hline \multirow{2}{*}{ Індикатори } & \multicolumn{7}{|c|}{ Роки } & \multirow{2}{*}{$\begin{array}{l}2018 \text { y } \\
\% \text { до } \\
2010 \text { p. }\end{array}$} \\
\hline & 2010 & 2013 & 2014 & 2015 & 2016 & 2017 & 2018 & \\
\hline $\begin{array}{l}\text { 1. Водоємність ВВП, куб. м ви- } \\
\text { користаної води на } 1000 \text { грн. } \\
\text { ВВП (у фактичних цінах) }\end{array}$ & 13,75 & 9,30 & 7,25 & 4,88 & 4,15 & 3,09 & 3,17 & 23,08 \\
\hline у\% до 2010 року & 100,0 & 67,6 & 52,7 & 35,5 & 30,2 & 22,5 & 23,1 & $X$ \\
\hline $\begin{array}{l}\text { 2.Індекс сільгосппродукції, \% до } \\
\text { попереднього року }\end{array}$ & 98,6 & 113,6 & 102,2 & 95,2 & 106,3 & 97,8 & 108,1 & $\mathrm{X}$ \\
\hline $\begin{array}{l}\text { 3. ВДВ сільського господарства, } \\
\text { млн. грн. }\end{array}$ & 82948 & 132354 & 161145 & 239806 & 279701 & 303949 & 361173 & 435,4 \\
\hline y\% до 2010 року & 100,0 & 159,6 & 194,3 & 289,1 & 337,2 & 366,4 & 435,4 & $X$ \\
\hline 4. Забір прісної води, млн. куб. м. & 5927 & 5087 & 3932 & 2989 & 3156 & 3196 & 4698 & 79,3 \\
\hline$y \%$ до $2010 p$ & 100,0 & 85,8 & 66,3 & 50,4 & 53,2 & 53,9 & 79,3 & $X$ \\
\hline $\begin{array}{l}\text { 5. Водоємність ВДВ сільського } \\
\text { господарства, куб. м. використа- } \\
\text { ної води на } 1000 \text { грн. ВДВ (у фа- } \\
\text { ктичних цінах) }\end{array}$ & 71,45 & 38,43 & 24,40 & 12,46 & 11,28 & 10,51 & 13,01 & 18,2 \\
\hline$y \%$ до $2010 p$ & 100,0 & 53,8 & 34,1 & 17,4 & 15,8 & 14,7 & 18,2 & $X$ \\
\hline
\end{tabular}

"Розраховано автором за даними Державної служби статистики України [11-14]

Проблема зниження водоємності ВДВ сільського господарства тісно пов'язана зі станом використання водних ресурсів у зрошуваному землеробстві. В Україні постійного зрошення потребують майже 19 млн. га орних земель, водночас площі фактичного поливу зрошуваних земель не перевищують $25 \%$ загальної площі. У державі офіційно обліковується 5,49 млн. га меліорованих земель, у т.ч. 2,18 млн. га зрошувальних; потенціал для розширення площі поливу досягає 1,5-1,8 млн. га земель. Сучасний стан меліоративного землеробства оцінюється як кризовий. Для відновлення дренажних систем на площі 1,95 млн. га потрібно близько 2,5 млрд. дол. інвестицій [17]. При цьому перевагу слід надавати інноваційним технологіям зрошення земель, що забезпечують підвищення рівня водовіддачі в аграрній сфері.

В ході оцінки ефективності використання ПРП сільського господарства доцільно враховувати втрати віртуальної води внаслідок домінуючої сировинної орієнтації вітчизняного агроекспорту. За даними Держстату, у 2018 р. частка експорту зернових культур у загальному експорті склала 15,3 \% (друге місце після чорних металів - 21\%), тоді як питома вага борошномельно-круп'яної продукції - всього 0,4 \% [14]. За оцінкою учених ДУ «Інститут економіки природокористування та сталого розвитку НАН України», загальний показник експорту віртуальної води фіксується на рівні 19,5 млрд. м ${ }^{3}$, що перевищує базові обсяги водокористування (11,3 млрд. м $\left.{ }^{3}\right)$ в Україні [6].

За імпортом показник віртуальної води складає 1,84 млрд. м $^{3}$ (таблиця 4). У вартісному виразі експортні потоки віртуальної води з України оцінюються у 8,5 млрд. грн. у внутрішніх і 11,55 млн. дол. у світових цінах. Різниця між імпортними й експорт- ними віртуальними водопотоками є від’ємною і досягає 3,04 млрд. грн. або 9,77 млн. дол., сигналізуючи про приховані втрати держави від домінуючого сировинного експорту.

Основний вплив на обсяги експорту віртуальної води здійснює агропромисловий комплекс (82\%), на обсяги імпорту - промисловість (94\%). Відповідно, Україна, експортуючи зернові культури, які є водоємним товаром, втрачає значні обсяги віртуальної води, якої в імпортних товарах є замало для утворення позитивної різниці. При цьому вітчизняне зерно переважно експортується в держави Близького Сходу та Азії, які таким чином покривають наявний дефіцит водних ресурсів за рахунок України [6].

Проведені розрахунки свідчать, що в нашій державі наявний відчутний дисбаланс за обсягами експорту та імпорту віртуальної води. До нього слід додати істотний ціновий дисбаланс: вартість обсягів експорту віртуальної води у внутрішніх цінах складає всього 2,9\% від аналогічного показника в світових цінах (2016 р), вартість обсягів імпорту - 12,1 \% (див. табл. 4). Таким чином, сировинна спрямованість зовнішньої торгівлі сприяє надмірному експорту віртуальної води за межі України, що генерує погрози національній політиці водоспоживання та втрати доданої вартості.

Іншим проявом негативного впливу сировинного експорту на природне середовище $\epsilon$ втрати поживних речовин. За дослідженнями д.е.н. М.В. Калінчика, з експортом зернових і олійних культур (включаючи побічну продукцію, спалену або експортовану в пелетах) Україна експортує 50 кг поживних речовин (NPK) на суму 16,5 млрд. грн. із 33 млн. га ріллі, а до країн-імпортерів надходить 170-450 кг NPK у розрахунку на 1 га ріллі [5]. 
Експорт-імпорт віртуальної води для України та її цінові параметри*

Таблиця 4

\section{-}

\begin{tabular}{|c|c|c|c|c|c|c|}
\hline \multirow{2}{*}{$\begin{array}{c}\text { Сектори еко- } \\
\text { номіки }\end{array}$} & \multirow[b]{2}{*}{ Показники } & \multirow{2}{*}{$\begin{array}{c}\text { Млн. м. } \\
\text { куб. }\end{array}$} & \multirow{2}{*}{$\begin{array}{l}\text { Вартість, } \\
\text { внутрішні } \\
\text { ціни, } \\
\text { млн. грн. }\end{array}$} & \multirow{2}{*}{$\begin{array}{c}\text { Вартість, } \\
\text { світові ціни, } \\
\text { млн. дол. }\end{array}$} & \multicolumn{2}{|c|}{ Вартість, внутрішні ціни: } \\
\hline & & & & & млн. дол. & $\begin{array}{c}\text { У \% до світо- } \\
\text { вої ціни }\end{array}$ \\
\hline \multirow{3}{*}{$\begin{array}{c}\text { Агропромис- } \\
\text { ловий ком- } \\
\text { плекс }\end{array}$} & 1.Експорт & 15899,3 & 6996,2 & 7950,2 & 273,8 & 3,4 \\
\hline & 2. Імпорт & 119,1 & 359,3 & 59,8 & 14,1 & 23,5 \\
\hline & 3. Різниця (2-1) & $-15780,2$ & $-6636,9$ & $-7890,4$ & $-259,7$ & $\mathrm{X}$ \\
\hline \multirow{3}{*}{ Промисловість } & 1.Експорт & 3604,4 & 1587,1 & 3604,4 & 62,1 & 1,7 \\
\hline & 2. Імпорт & 1728,2 & 5184,4 & 1728,2 & 202,9 & 11,7 \\
\hline & 3. Різниця (2-1) & $-1876,2$ & 3597,3 & $-1876,2$ & 140,8 & $\mathrm{X}$ \\
\hline \multirow{3}{*}{ Разом } & 1.Експорт & 19503,7 & 8583,3 & 11554,6 & 335,9 & 2,9 \\
\hline & 2. Імпорт & 1847,3 & 5543,7 & 1788 & 217,0 & 12,1 \\
\hline & 3. Різниця (2-1) & $-17656,4$ & $-3039,6$ & $-9766,6$ & $-119,0$ & $\mathrm{X}$ \\
\hline
\end{tabular}

"Складено за даними досліджень ДУ «Інститут економіки природокористування та сталого розвитку НАН України» [6]

У ході використання ПРП сільського господарства важливо мінімізувати його екодеструктивний вплив на стан навколишнього середовища, зокрема, зменшити величину утворених відходів та збільшити обсяги їх переробки і повторного використання на основі інноваційних технологій. Для оцінки негативного впливу агросфери на стан природного середовища у межах впровадження ЦСР 12 «Відповідальне споживання та виробництво» нами запропоновано декілька індикаторів, зокрема, відходоємність ВДВ сільського господарства, який є секторальним показником екологічної продуктивності ВДВ (див. табл. 1). Головні індикатори утворення відходів та відходоємності ВВП на національному та секторальному рівні представлено в таблиці 5 .

Індикатори утворення відходів та відходоємності ВДВ сільського господарства України"

\begin{tabular}{|c|c|c|c|c|c|c|c|}
\hline \multirow{2}{*}{ Індикатори } & \multicolumn{7}{|c|}{ Роки } \\
\hline & 2010 & 2013 & 2014 & 2015 & 2016 & 2017 & 2018 \\
\hline $\begin{array}{l}\text { 1.Обсяги утворених відходів I-IV класів } \\
\text { в Україні, тис. т }\end{array}$ & 425914 & 448118 & 355000 & 312268 & 295870 & 366054 & 352334 \\
\hline$y \%$ до $2010 p$ & 100,0 & 105,2 & 83,4 & 73,3 & 69,5 & 85,9 & 82,7 \\
\hline $\begin{array}{l}\text { 2.Частка спалених та утилізованих від- } \\
\text { ходів у загальному обсязі утворених } \\
\text { відходів, \% }\end{array}$ & 34,5 & 33,0 & 31,0 & 30,0 & 29,0 & 27,6 & 29,7 \\
\hline $\begin{array}{l}\text { 3. Відходоємність ВВП у фактичних } \\
\text { цінах, кг/тис. грн. }\end{array}$ & 394,6 & 305,8 & 223,7 & 157,0 & 124,0 & 122,7 & 99,0 \\
\hline $\begin{array}{l}\text { 4.Обсяги утворених відходів I-IV класів } \\
\text { у сільському господарстві, тис. т }\end{array}$ & 8305 & 10081 & 8451 & 8737 & 8716 & 6188 & 5968 \\
\hline$y \%$ до $2010 p$ & 100,0 & 146,9 & 120,8 & 121,4 & 101,8 & 105,2 & 104,9 \\
\hline $\begin{array}{l}\text { 5.Частка утворених відходів у сільсько- } \\
\text { му господарстві в загальному обсязі } \\
\text { утворених відходів в економіці,\% }\end{array}$ & 1,95 & 2,25 & 2,38 & 2,80 & 2,95 & 1,69 & 1,69 \\
\hline $\begin{array}{l}\text { 6. Відходоємність ВДВ сільського гос- } \\
\text { подарства у фактичних цінах, } \\
\text { кг/тис. грн. }\end{array}$ & 100,1 & 76,2 & 52,4 & 36,4 & 31,2 & 20,4 & 16,5 \\
\hline y\% до 2010 p. & 100,0 & 76,1 & 52,4 & 36,4 & 31,1 & 20,3 & 16,5 \\
\hline
\end{tabular}

\footnotetext{
"Розраховано автором за даними Державної служби статистики України [11-14]
} 
У 2018 р. обсяг утворених відходів I-IV класів в Україні склав 352,3 млн. тонн, у т.ч. в сільському господарстві - 5,97 млн. т. або 1,69 \% від загального обсягу (див. табл. 5). Частка спалених та утилізованих відходів у загальному обсязі утворених відходів у звітному році досягла 29,7\%, зменшившись порівняно з 2010 р. на 4,8 \%, не досягнувши цільового індикатора 2020 р. (35\%). Відходоємність ВВП у цілому по економіці склала 99 кг/тис. грн. - 25 \% від рівня 2010 р. Головними чинниками, що обумовили тенденцію зниження індикатора, є зменшення обсягів утворених відходів внаслідок скорочення виробництва добувної промисловості і розроблення кар'єрів, яка генерує понад 80 \% відходів у країні, на фоні зрос- тання ВВП у фактичних цінах.

Індикатор відходоємності ВДВ сільського господарства у 2018 р. досягнув 16,5 кг / тис. грн. (для порівняння: аналогічний показник для добувної промисловості склав 1407 кг / тис. т), що є свідченням порівняно невисокого деструктивного впливу агросектору на природне середовище. Наявна тенденція до скорочення індикатора (майже на $80 \%$ порівняно 3 2010 р.) обумовлена зростанням ВДВ у фактичних цінах за одночасного скорочення величини утворених відходів у сільському господарстві (рис. 3), у т.ч. за рахунок збільшення екологічних інвестицій на поводження з відходами.

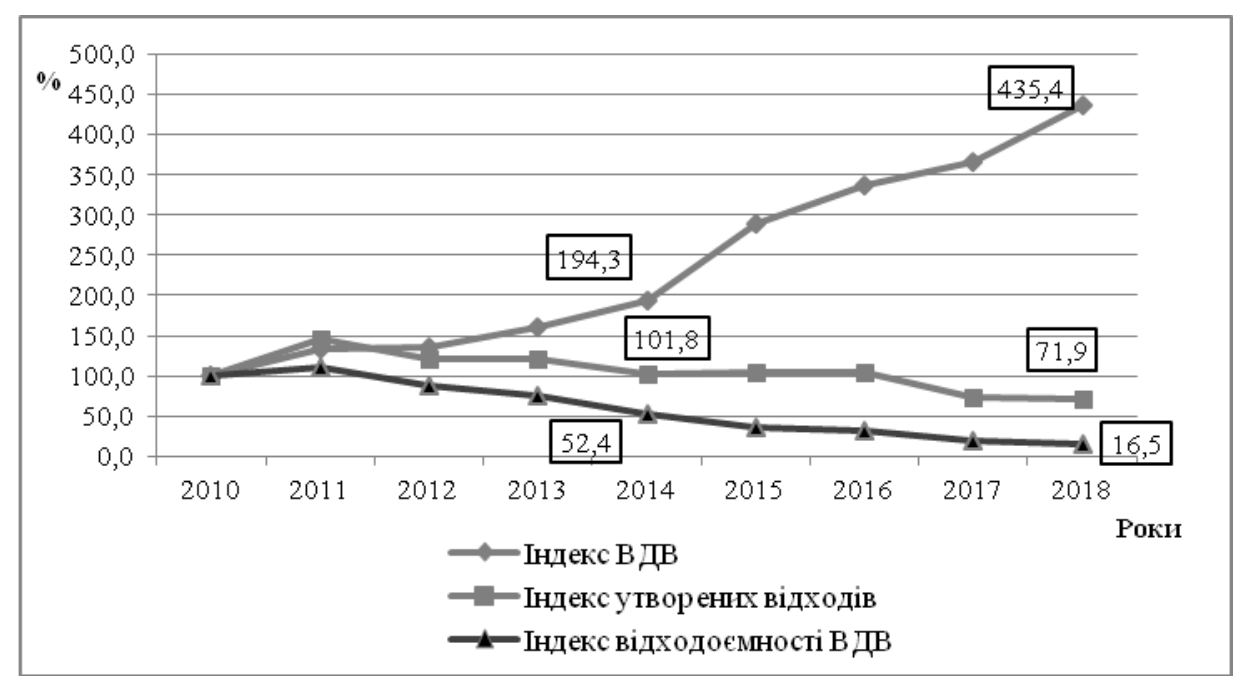

Рис. 3. Динаміка індексів ВДВ, утворених відходів та відходосмності ВДВ сільського господарства України, \% (2010 р. - $100 \%)^{*}$ *Побудовано автором за даними табл. 3, 5.

Важливим завданням на шляху раціонального природокористування є конструктивна інвестиційна політика, зорієнтована на охорону та відновлення ПРП сільського господарства (див. табл. 1). У 2018 р. частка капітальних інвестицій на охорону природного середовища в Україні склала 1,74 \%, що на 0,28\% вище рівня 2010 р., але на 1,99\% нижче величини 2016 р. (таблиця 6). Питома вага капітальних інвестицій сільського господарства у загальнодержавному показнику досягає 11,42 \%. У звітному році величина інвестицій на охорону природного середовища в агросекторі склала 8,89 млн. грн., зменшившись порівняно з 2010 р. на 82,3 \%, на фоні зростання загального секторального показника в 5,7 рази. Питома вага екологічних капітальних інвестицій сільського господарства у загальному їх обсязі є мізерною - 0,013 \% у 2018 р. проти $0,426 \%$ у 2010 р.

Динаміка капітальних інвестицій на охорону природного середовища в сільському господарстві України*

\begin{tabular}{|c|c|c|c|c|c|c|c|c|}
\hline \multirow{2}{*}{ Індикатори } & \multicolumn{7}{|c|}{ Роки } & \multirow{2}{*}{$\begin{array}{l}\text { 2018p. y \% } \\
\text { до 2010p. }\end{array}$} \\
\hline & 2010 & 2013 & 2014 & 2015 & 2016 & 2017 & 2018 & \\
\hline $\begin{array}{l}\text { 1. Капітальні інвестиції на охорону } \\
\text { природного середовища в Україні, \% } \\
\text { до загальних капітальних інвестицій }\end{array}$ & 1,46 & 2,26 & 3,63 & 2,81 & 3,73 & 2,46 & 1,74 & $X$ \\
\hline $\begin{array}{l}\text { 2. Капітальні інвестиції у сільське } \\
\text { господарство, млн. грн. всього }\end{array}$ & 11568 & 19059 & 18796 & 30155 & 50484 & 64243 & 66104 & 571,4 \\
\hline $\begin{array}{l}\text { y\% до загальних капітальних інве- } \\
\text { стицій }\end{array}$ & 6,12 & 7,12 & 8,57 & 11,04 & 14,05 & 14,33 & 11,42 & $X$ \\
\hline $\begin{array}{l}\text { 3. Капітальні інвестиції на охорону } \\
\text { природного середовища у сільському } \\
\text { господарстві, млн.. грн. }\end{array}$ & 49,3 & 187,7 & 23,0 & 22,4 & 43,7 & 50,4 & 8,9 & 17,7 \\
\hline $\begin{array}{c}\text { у\% до загальних капітальних ін- } \\
\text { вестииій сільського господарства, \% }\end{array}$ & 0,426 & 0,985 & 0,122 & 0,074 & 0,087 & 0,078 & 0,013 & $X$ \\
\hline
\end{tabular}

"Розраховано автором за даними Державної служби статистики України [11-14] 
Відповідно, за існуючого рівня інвестування (див. табл. 6) процес розширеного відтворення та охорони ПРП сільського господарства є вкрай обмеженим, що обумовлює необхідність розробки та впровадження інвестиційно-інноваційного механізму раціонального природокористування.

Висновки та перспективи подальших досліджень. Розроблені автором методичні положення щодо комплексної оцінки ПРП аграрного сектору національної економіки поєднали у єдину систему ключові індикатори чотирьох ЦСР $(2,6,12,15)$, показники «зеленого» зростання в частині ресурсної продуктивності та інвестиційного забезпечення, авторські індикатори з акцентом на показники ресурсної й екологічної продуктивності ВДВ сільського господарства. Комплементарність інтегрованих у систему індикаторів дає можливість вирішувати подвійне завдання: діагностувати стан використання й відновлення ПРП агросфери та здійснювати моніторинг ЦСР в країні для встановлення прогресу або регресу у тенденціях сталого розвитку.

Проведені емпіричні дослідження на основі розробленого методичного базису дозволили визначити низку тенденцій у використанні ПРП сільського господарства. До позитивних тенденцій слід віднести перманентне зростання площ органічних угідь (базовий індекс - $150 \%$ ), зменшення обсягів утворених відходів (71,9\%), скорочення відходоємності ВДВ агросектору (16,5\%). До негативних тенденцій доцільно віднести подвійне зростання обсягів мінеральних добрив, внесених під посіви аграрних культур (203\%), на фоні мізерного приросту органічних добрив (108\%); від'ємні баланси гумусу та поживних речових в грунтах України; скорочення водоємності ВДВ агросектору (18,2\%) через кризовий стан зрошувального землеробства; приховані втрати віртуальної води внаслідок домінуючої сировинного орієнтації вітчизняного агроекспорту; знижувальний тренд капітальних інвестицій на охорону природного середовища $(17,7 \%)$.

Одним із шляхів поліпшення водозабезпеченості сільського господарства $є$ накопичення експортних потоків віртуальної води в межах країни та стимулювання імпорту водоємної продукції. Для цього необхідно змінити структуру експортно-імпортних операцій у бік зниження обсягів експорту сировинних товарів, зокрема, зернових культур, які містять значні обсяги віртуальної води, витрачені на їх виробництво. 3 огляду на необхідність покращення стану грунтів, впровадження стратегії розвитку зрошувального землеробства, нагальним завданням постає розробка інвестиційно-інноваційного механізму раціонального природокористування в Україні.

Наукова новизна проведеного дослідження полягає в удосконаленні методичного забезпечення комплексної оцінки ПРП сільського господарства на засадах сталого розвитку, яке базується на множині наукових принципів, комплементарності ключових індикаторів сталого розвитку, «зеленого» зростання та авторських показників, що всебічно охоплюють характеристики компонентів природно-ресурсного потенціалу агросфери та орієнтовані на механізми стимулювання його ефективного використання. Прикладне значення отриманих результатів визначається можливістю їх використання державними й профільними інституціями, різними групами стейкхолдерів у ході діагностики прогресу сталого розвитку, обгрунтування стратегічних напрямів і заходів його стимулювання в агросфері. Перспективи подальших досліджень полягають у розширенні системи ключових індикаторів для комплексної оцінки ПРП сільського господарства, проведення міжсекторальних порівнянь показників ресурсної й екологічної продуктивності ВДВ різних секторів економіки, як аналітичного підгрунтя для формування інвестиційно-інноваційної політики раціонального природокористування в національній економіці.

\section{Література}

1. Цілі Сталого розвитку 2016-2030. URL: http://www.un.org.ua/ua/tsili-rozvytku-tysiacholittia/tsilistaloho-rozvytku (дата звернення 06.02.2020).

2. Про Цілі сталого розвитку України на період до 2030 року: Указ Президента України від 30 вересня 2019 р. № 722/2019. URL: https://zakon.rada.gov.ua/laws/show/722/2019 (дата звернення 06.02.2020).

3. Стратегія сталого розвитку України до 2030 року (проект). URL: https://www.undp.org/content/dam/ukraine/docs/SDGreports/UNDP_Strategy_v06-optimized.pdf (дата звернення 06.02.2020).

4. Дребот О.І., Гадзало А.Я. Напрями інвестиційно інноваційного механізму збалансованого природокористування. Науковий вісник Херсонского державного університету. Серія Економічні наук. 2016. Вип.19. Ч.1. С.118-121.
5. Калінчик М.В.
Стратегія
безвиході
поведінки
на
землі.
URL: https://day.kyiv.ua/uk/article/ekonomika/strategiya-bezvyhodi-povedinky-na-zemli

6. Хвесик M.A, Сундук А.M. Віртуальна вода: міф чи реальність? URL: https://dt.ua/ECOLOGY/virtualna-voda-mif-chi-realnist-_.html (дата звернення 06.02.2020).

7. Ц Цілі Сталого Розвитку: Україна: Національна доповідь 2017. Київ: Міністерство економічного розвитку і торгівлі України, 2017. 176 с.

8. Методичні положення та рекомендації щодо визначення економіко-екологічних пріоритетів «зеленої економіки» у контексті сталого розвитку України / Буркинський Б.В., Лайко О.І, Хумарова Н.I. та ін. Одеса : ІПРЕЕД НАН України, 2019. 48 с. 
9. Методичні рекомендації до оцінки впливу економічних показників на головні індикатори «зеленого» зростання / Буркинський Б.В., Нікішина О.В., Андрєєва Н.М. та ін. Одеса: ІПРЕЕД НАН України, 2019. 45 c.

10. Доповідь про зелену трансформацію в Україні на основі показників зеленого зростання ОЕСР. Київ: Міністерство економічного розвитку і торгівлі України, 2016. 60 с.

11. Статистичний щорічник України за 2018 рік / за ред. І.Є.Вернера. Київ: Державна служба статистики України, 2019.482 с.

12. Довкілля України за 2017 рік: статистичний збірник / за ред. О. М. Прокопенко. Київ: Державна служба статистики України, 2018. 225 с.

13. Довкілля України за 2018 рік: статистичний збірник / за ред. О. М. Прокопенко. Київ: Державна служба статистики України, 2019. 214 с.

14. Офіційний сайт Державної служби статистики України. URL: http://www.ukrstat.gov.ua/ (дата звернення 06.02.2020).

15. Позиції України в рейтингу екологічної ефективності в 2018 році. URL: http://edclub.com.ua/analityka/pozyciyi-ukrayiny-v-reytyngu-ekologichnoyi-efektyvnosti-u-2018-roci (дата звернення 06.02.2020).

16. Національна доповідь про стан навколишнього природного середовища у 2013 році. Міністерство екології та природних ресурсів України. Київ, 2015. 289 с.

17. Система зрошувального землеробства в Україні: проблеми, вартість та шляхи вирішення. URL: https://landlord.ua/news/systema-zroshuvalnoho-zemlerobstva-v-ukraini-problemy-vartist-ta-shliakhy-vyrishennia/ (дата звернення 06.02.2020).

\author{
Никишина О.В. \\ доктор экономических наук, старший научный сотрудник, \\ начальник отдела рыночных механизмов и структур \\ Институт проблем рынка и экономико- \\ экологических исследований НАН Украины \\ Французский бульвар, 29, г. Одесса, Украина, 65044 \\ E-mail: ksenkych@gmail.com. \\ ORCID ID: 0000-0002-7172-3551
}

\title{
МЕТОДИЧЕСКИЕ ПОЛОЖЕНИЯ ПО ОЦЕНКЕ ПРИРОДНО- РЕСУРСНОГО ПОТЕНЦИАЛА СЕЛЬСКОГО ХОЗЯЙСТВА В КООРДИНАТАХ УСТОЙЧИВОГО РАЗВИТИЯ УКРАИНЫ
}

В статье разработаны методические положения по комплексной оценке компонентов природноресурсного потенциала сельского хозяйства в контексте устойчивого развития. Обоснована система комплементарных индикаторов устойчивого развития, «зеленого» роста и авторских показателей в соответствии с такими научными принципами: (1) комплексность и взаимосвязанность; (2) объективность и достоверность; (3) возможность межсекторального сравнения; (4) целенаправленность; (5) гибкость и научность; (6) транспарентность - открытость для стейкхолдеров. Такая система индикаторов призвана обеспечить всестороннюю оценку использования, трансформации, восстановления и охраны природноресурсного потенциала аграрного сектора сквозь призму устойчивого развития. Предложен ряд авторских показателей с акцентом на индикаторы ресурсной и экологической продуктивности валовой добавленной стоимости сельского хозяйства.

С использованием разработанных методических положений проведена оценка состояния некоторых компонентов природно-ресурсного потенциала агросектора, в частности, земельных и водных ресурсов, сферы обращения с отходами и инвестиционного обеспечения рационального природопользования. По результатам оценки определены положительные и отрицательные тенденции в использовании ресурсного потенциала агросферы. К положительным тенденциям отнесено стабильный рост площадей органических угодий, уменьшение объемов образуемых отходов, к негативным - неудовлетворительное состояние почв, потери виртуальной воды из-за наращивания сырьевого экспорта, уменьшение объемов экологических инвестиций в сельском хозяйстве. Обоснована необходимость внедрения инвестиционно-инновационного механизма рационального природопользования в Украине. 
Научная новизна проведенного исследования состоит в усовершенствовании методического обеспечения оценки природно-ресурсного потенциала аграрного сектора на основе устойчивого развития. Перспективы дальнейших исследований заключаются в расширении системы комплементарных индикаторов, развитии и апробации методик их диагностики.

Ключевые слова: природно-ресурсный потенциал, устойчивое развитие, аграрный сектор, индикаторы, оценка, рациональное природопользование.

\author{
Nikishyna 0. \\ Doctor of Economics, Senior Researcher \\ Head of Department of Market Mechanisms and Structures \\ Institute of Market Problems and Economic \& Ecological Research \\ of National Academy of Sciences of Ukraine \\ Frantsuzskiy boulevard, 29, Odesa, Ukraine, 65044 \\ E-mail: ksenkych@gmail.com \\ ORCID ID: 0000-0002-7172-3551
}

\title{
METHODICAL PROVISIONS FOR THE EVALUATION OF THE NATURAL RESOURCE POTENTIAL OF AGRICULTURE IN THE COORDINATES OF SUSTAINABLE DEVELOPMENT OF UKRAINE
}

The article elaborates methodical provisions for the integrated assessment of components of agriculture's natural resource potential in the context of sustainable development. The system of complementary indicators of sustainable development, green growth and authoritative indicators in accordance with the following scientific principles has been justified: (1) complexity and interconnectedness; (2) objectivity and reliability; (3) cross-sectoral comparability; (4) purposefulness; (5) flexibility and being science-based; (6) transparency openness to stakeholders. Such system of indicators aims to provide a comprehensive assessment of use, transformation, restoration and protection of the natural resource potential of the agricultural sector through the lens of sustainable development. A number of copyright indicators have been proposed with a focus on indicators of resource and environmental productivity of gross value added in agriculture.

Using the developed methodical provisions, the state evaluation of the of some components of the natural resource potential of the agricultural sector, in particular, land and water resources, the sphere of waste management and investment support for rational use of nature, have been evaluated. According to the results of the evaluation, positive and negative tendencies in the use of the resource potential of the agricultural sector were identified. Positive trends include stable growth of organic lands, decrease in the amount of waste generated, negative ones include unsatisfactory soil condition, loss of virtual water due to increase of raw materials exports, decrease of ecological investments in agriculture. The necessity of introduction of the investmentinnovative mechanism of rational nature management in Ukraine has been substantiated.

The scientific novelty of the conducted research is to improve methodical support for the assessment of the natural resource potential of the agricultural sector on the basis of sustainable development. Prospects for further research are to expand the system of complementary indicators, to develop and make approbation of methods for their diagnosis.

Key words: natural resource potential, sustainable development, agrarian sector, indicators, evaluation, sustainable use of nature.

\section{References}

1. Tsili Staloho rozvytku 2016-2030. (2015). Retrieved February 6, 2020, from http://www.un.org.ua/ua/tsilirozvytku-tysiacholittia/tsili-staloho-rozvytku

2. Pro Tsili staloho rozvytku Ukrainy na period do 2030 roku. (2019). Retrieved February 6, 2020, from https://zakon.rada.gov.ua/laws/show/722/2019

3. Stratehiia staloho rozvytku Ukrainy do 2030 roku (proekt). (2017). Retrieved February 6, 2020, from https://www.undp.org/content/dam/ukraine/docs/SDGreports/UNDP_Strategy_v06-optimized.pdf

4. Drebot, O. I., \& Hadzalo, A. Ya. (2016). Napriamy investytsiino innovatsiinoho mekhanizmu zbalansovanoho pryrodokorystuvannia. Naukovyi Visnyk Khersonskoho Derzhavnoho Universytetu, (19. Ch.1.), 118-121.

5. Kalinchyk, M. V. (2019). Stratehiia bezvykhodi povedinky na zemli. Retrieved February 6, 2020, from https://day.kyiv.ua/uk/article/ekonomika/strategiya-bezvyhodi-povedinky-na-zemli

6. Khvesyk, M. A., \& Sunduk, A. M. (2016). Virtualna voda: mif chy realnist? Retrieved February 6, 2020, from https://dt.ua/ECOLOGY/virtualna-voda-mif-chi-realnist-_.html

7. Ministerstvo ekonomichnoho rozvytku i torhivli Ukrainy. (2017). Tsili Staloho Rozvytku (pp. 01-176). Kyiv. 
8. Burkynskyi, B. V., Laiko, O. I., \& Khumarova, N. I. (2019). Metodychni polozhennia ta rekomendatsii shchodo vyznachennia ekonomiko-ekolohichnykh priorytetiv «zelenoi ekonomiky» u konteksti staloho rozvytku Ukrainy. Odesa: IPREED NAN Ukrainy.

9. Burkynskyi, B. V., Nikishyna, O. V., \& Andrieieva, N. M. (2019). Metodychni rekomendatsii do otsinky vplyvu ekonomichnykh pokaznykiv na holovni indykatory «zelenoho» zrostannia. Odesa: IPREED NAN Ukrainy.

10. Ministerstvo ekonomichnoho rozvytku i torhivli Ukrainy. (2016). Dopovid pro zelenu transformatsiiu $v$ Ukraini na osnovi pokaznykiv zelenoho zrostannia Oesr (pp. 01-60). Kyiv.

11. Verner, I. Ye. (Ed.). (2019). Statystychnyi shchorichnyk Ukrainy za 2018 rik. Kyiv: Derzhavna sluzhba statystyky Ukrainy.

Ukrainy.

12. Prokopenko, O. M. (Ed.). (2018). Dovkillia Ukrainy za 2017 rik. Kyiv: Derzhavna sluzhba statystyky Ukrainy.

13. Prokopenko, O. M. (Ed.). (2019). Dovkillia Ukrainy za 2018 rik. Kyiv: Derzhavna sluzhba statystyky

14. Ofitsiinyi sait Derzhavnoi sluzhby statystyky Ukrainy. Retrieved February 6, 2020, from http://www.ukrstat.gov.ua/

15. Pozytsii Ukrainy v reitynhu ekolohichnoi efektyvnosti v 2018 rotsi. (2018). Retrieved February 6, 2020, from http://edclub.com.ua/analityka/pozyciyi-ukrayiny-v-reytyngu-ekologichnoyi-efektyvnosti-u-2018-roci

16. Ministerstvo ekolohii ta pryrodnykh resursiv Ukrainy. (2015). Natsionalna dopovid pro stan navkolyshnoho pryrodnoho seredovyshcha u 2013 rotsi (pp. 01-289). Kyiv.

17. Systema zroshuvalnoho zemlerobstva v Ukraini: problemy, vartist ta shliakhy vyrishennia. (2019). Retrieved February 6, 2020, from https://landlord.ua/news/systema-zroshuvalnoho-zemlerobstva-v-ukraini-problemyvartist-ta-shliakhy-vyrishennia/

Received 12 February 2020

Approved 26 February 2020

Available in Internet 31.03.20

Цитування згідно ДСТУ 8302:2015

Нікішина О.В. Методичні положення щодо оцінки природно-ресурсного потенціалу сільського господарства у координатах сталого розвитку України // Економіка харчової промисловості. 2020. Т.12, вип. 1. С. 64-76. doi: 10.15673/fie.v12i1.1670

Cite as APA style citation

Nikishyna, O. (2020). Methodical provisions for the evaluation of the natural resource potential of agriculture in the coordinates of sustainable development of Ukraine. Food Industry Economics, 12(1), 64-76. doi: 10.15673/fie.v12i1.1670 